\section{Oversiktlig lærebok om epilepsi hos barn og ungdom}

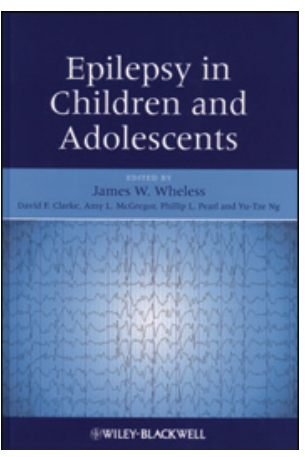

James W. Wheless, David F. Clarke, Amy L. McGregor et al, red.

Epilepsy in children and adolescents 378 s, tab, ill. Chichester: Wiley-Blackwell, 2012. Pris GBP 100

ISBN 978-0-470-74123-8

Dette er en lærebok som gir en oversiktlig, kortfattet og god innføring i epilepsi som oppstår i barne- og ungdomsårene. Forfatterne er amerikanske barnenevrologer/epileptologer, som også har betydelig vitenskaplig erfaring med tallrike publikasjoner bak seg. Referansene er omfattende og oppdaterte og gir god mulighet til videre fordypning. Dette er åpenbart ment som en innføring i et stort tema, og noen kapitler er etter mitt skjønn vel summariske. At boken er på engelsk er ingen hindring ettersom språket er enkelt og lettfattelig.

Boken åpner med epidemiologi og psykososiale forhold. I dette fagfeltet har det vært et paradigmeskifte i den senere tid, idet man ikke lenger ser på psykiatriske lidelser kun som forårsaket av de psykososiale belastningene som ofte følger med diagnosen. Forfatterne legger stor vekt på patofysiologiske fellesnevnere ved epilepsi og psykiatri.

$\mathrm{AD} / \mathrm{HD}$, angst og depresjon er beskrevet som de hyppigst forekommende komorbide tilstandene. Den omdiskuterte advarselen fra U.S. Food and Drug Administration om økt risiko for suicidalitet ved behandling med antiepileptika er også kort omtalt. Jeg savner en bredere omtale av kognitive problemer hos barn med epilepsi. Det er relevant både hos barn som fungerer innen «normalområdet» og hos barn med psykisk utviklingshemning og epilepsi. Det første kapitlet har kun noen få ord om dette.

Boken dekker de viktigste epilepsisyndromene som debuterer i barne- eller ungdomstiden, med forekomst, ytringsform, diagnostikk og behandling. Under utredning er både EEG og bildediagnostikk viktig, og dette er viet egne kapitler. Det er mange illustrative eksempler på EEG ved forskjellige epilepsisyndromer, og det finnes også en nyttig oversikt over hvilken undersøkelse som bør rekvireres ved forskjellige problemstillinger.

Forfatterne har gitt en svært kort beskrivelse av klassifikasjon av anfall. Dette er såpass fundamentalt at jeg synes det burde vært dekket bredere. Det har blant annet relevans for valg av antiepileptikum.

Boken inneholder oppdatert informasjon om behandling i form av kirurgi og ketogen diett. De fleste klinikere vil allikevel ha mest nytte av kapitlene om antiepileptika. Forfatterne beskriver godt hvilke avveininger som må gjøres ved oppstart og seponering av medikamenter, og det er et eget kapittel om bivirkninger. Det er også et svært leseverdig kapittel om antiepileptika, farmakokinetikk og interaksjonerer.

Jeg anbefaler boken for lesere som ønsker en kortfattet, praktisk og oppdatert innføring i dette emnet.

Kristin Å. Alfstad

Avdeling for kompleks epilepsi - SSE

Oslo universitetssykehus

\section{Fin oversikt over praksis og teori i farmakologien}

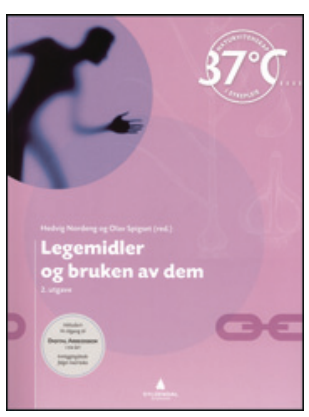

Hedvig Nordeng, Olav Spigset, red. Legemidler og bruken av dem

2. utg. 420 s, tab, ill. Oslo: Gyldendal

Akademisk, 2013. Pris NOK 649

ISBN 978-82-05-42506-4

Boken er beregnet for sykepleiestudenter og er en del av den naturvitenskapelige kunnskapspakken $37^{\circ} \mathrm{C}$ fra Gyldendal, som består av fem lærebøker og et felles nettsted. Redaktørene mener at boken også er aktuell for blant andre medisinstudenter, og det må jeg si meg enig $i$.

Først og fremst er layouten veldig fin. Sidene er oversiktlige og nesten elegante, og det er god balanse mellom tekst, bilder, oppsummeringstabeller, kliniske eksempler og spesielle tips til sykepleieren. De fire delene består av en generell del om farmakologi, to deler om spesifikke medikamenter og bruken av dem og til slutt en del med spesielle emner.

Jeg ble særlig begeistret over den generelle delen som blant annet omhandler farmakodynamikk, farmakokinetikk, bivirkninger og interaksjoner. Som en introduksjon til disse emnene er boken kjempeflott, og et godt tips til medisinstudenter som ønsker å få en oversikt og sammenheng enten før eller etter dette gjennomgås på studiet.

De to mer spesifikke delene om legemidler som påvirker sykdomsprosesser og om legemidler ved sykdommer i organsystemene, kan være greie som en introduksjon til temaene, men blir likevel for korte når det kommer til stykket. For disse temaene er det kanskje like greit å lese i egen pensumlitteratur for medisinstudiet. Delen om spesielle emner, derimot, er nyttig for også medisinstudenter, da den omhandler emner som ikke nødvendigvis blir oppsummert eller undervist i på en samlet måte. Her omtaler forfatterne blant annet spesielle hensyn ved legemiddelbruk hos barn og eldre, rusmisbruk, naturmedisin og smerter. Når får vi for eksempel lært om interaksjoner mellom naturmedisiner og legemidler? Eller hvordan man helst bør gi barn medisin med doseringssprøyte? Denne læreboken er en god kilde til praktiske tips og viktige kliniske poeng som man i farmakologiundervisningen på medisinstudiet ofte ikke tar seg tid til.

Jeg har gang på gang vært frustrert over at vi lærer mye teori og detaljer i farmakologiundervisningen, men at vi for eksempel ikke vet hvordan vi rent praktisk skal forholde oss til ulike pasientgrupper og medikamenter. Dette lærer vi forhåpentligvis i praksis senere, men som en introduksjon eller påminnelse om mange viktige praktiske forhold, er Legemidler og bruken av dem helt suveren. I tillegg tror jeg mange medisinstudenter vil kunne ha nytte av den, enten som en introduksjon til farmakologi, eller som en repetisjon av de viktigste prinsippene senere.

\section{Ane Brandtzæg Næss}

Universitetet i Oslo 